\title{
THE BAMBOOS OF NEPAL AND BHUTAN \\ PART II: Arundinaria, Thamnocalamus, Borinda, and Yushania (Gramineae: Poaceae, Bambusoideae)
}

\author{
C. M. A. STAPLETON*
}

\begin{abstract}
This paper continues the systematic treatment of the bamboos of Nepal and Bhutan, covering four hardy temperate genera with semelauctant inflorescences and 3 stamens from the subtribe Arundinariinae Bentham. Arundinaria Michaux has leptomorph rhizomes, while Thamnocalamus Munro, Yushania Keng f., and the new genus Borinda have pachymorph rhizomes. The separation of these and related Sino-Himalayan genera is discussed. Sinarundinaria Nakai is treated as a synonym of Fargesia Franchet, a genus that is not known from the Himalayas. A new treatment of Himalayan Thamnocalamus species is given, including the description of two new subspecies of Thamnocalamus spathiflorus (Trin.) Munro, subsp. nepalensis and subsp. occidentalis, and one new variety, bhutanensis. T. aristatus is treated as a synonym of T. spathiflorus subsp. spathiflorus, and Fargesia crassinoda $\mathrm{Yi}$ is transferred and given new status as Thamnocalamus spathiflorus (Trin.) Munro var. crassinodus (Yi) Stapleton. Two new species of Borinda are described: $B$. chigar from West Nepal and B. emeryi from East Nepal. Six species of Fargesia from Tibet are transferred to Borinda, which thus comprises eight species.
\end{abstract}

\section{STATUS AND SEPARATION OF THE GENERA}

Bamboos from the mountains of the Indian subcontinent and China with 3 stamens and terete culms were all placed in Arundinaria Michaux until late in the 19th century, when two genera for bamboos with spathate inflorescences were described. Munro (1868) described Thamnocalamus as a Himalayan genus with groups of one to four racemes at the tips of branchlets, each raceme being enclosed in a spathe. Franchet (1893) described Fargesia as a Chinese genus with spikelets grouped together in a single unilateral cluster enclosed in a spathe. Although Gamble (1896) reduced Thamnocalamus to a synonym of Arundinaria, it has been recognized consistently by subsequent authorities. Fargesia has received less recognition. Keng (1983) and Soderstrom \& Ellis (1987) recognized it as a separate genus, but Clayton \& Renvoize (1986) and Chao \& Renvoize (1989) treated it as a synonym of Thamnocalamus.

The large group of Sino-Himalayan bamboos with simple, open, semelauctant inflorescences without enclosing spathes has also received conflicting treatments. The possession of leptomorph (monopodial or amphipodial) rhizome axes is now widely accepted to be an important characteristic in the bamboos. In this group of bamboos such rhizomes are found only in Arundinaria Michaux and Chimonobambusa Makino. All other bamboos have determinate pachymorph (sympodial) rhizomes and a substantially higher number of branches, and all authorities would agree that there is a large group of species that cannot be accommodated in Arundinaria, Chimonobambusa, or Thamnocalamus. This group is characterized by the combination of simple, unspathed, loose inflorescences, pachymorph rhizomes, and several branches.

\footnotetext{
* Formerly Royal Botanic Garden, Edinburgh. Present address: Royal Botanic Gardens, Kew, Richmond, Surrey,
} TW9 3 AE. 
Nakai (1935) described Sinarundinaria for two Chinese bamboos cultivated in the west that apparently came from this broad group, $S$. nitida and $S$. murielae, and the genus became widely recognized. Nakai's description was inaccurate, however, attributing the genus incorrectly with leptomorph rhizomes and multiple branch buds, and it did not cover the flowers, which were not known at that time. Sinarundinaria murielae Nakai began to flower in the 1970s. The flowers were spathed and similar to those of the type species of Fargesia, F. spathacea. Fargesia was considered at that time to be a synonym of Thamnocalamus (Soderstrom, 1979a), and $S$. murielae was consequently transferred to Thamnocalamus as a synonym of $T$. spathaceus (Soderstrom, 1979b), although Soderstrom later recognized Fargesia as a separate genus (Soderstrom \& Ellis, 1987). The flowers of the type species, S. nitida, remained unknown, however, and several authorities continued to place most species with 3 stamens, pachymorph rhizomes and loose semelauctant inflorescences in Sinarundinaria.

Several other genera of 3-stamened, pachymorph-rhizomed bamboos with loose inflorescences have been described in China. These genera have all been treated as synonyms of Sinarundinaria by those who have recognized that genus. The first genus to be described after Sinarundinaria was Yushania Keng f., with type species $Y$. niitakayamensis from Taiwan, a species with open inflorescences and pachymorph rhizomes with very long necks. Chao et al. (1980) argued vigorously for the treatment of Yushania as a synonym of Sinarundinaria, a treatment followed by Clayton \& Renvoize (1986) and Chao \& Renvoize (1989).

The initiation of flowering in 1993 of the type species of Sinarundinaria, S. nitida (Renvoize, 1993), has eventually confirmed that this species is also congeneric with the type species of the earlier genus Fargesia (Franchet, 1893), having unilateral spathed inflorescences similar to those of both Fargesia spathacea and Sinarundinaria murielae. Most authorities who recognized Sinarundinaria clearly considered Fargesia to be a synonym of Thamnocalamus, and would presumably now treat both Fargesia and Sinarundinaria as synonyms of Thamnocalamus. However, this would make the genus large and extremely heterogeneous.

Demoly (1991) continued to include Fargesia (with its new synonym Sinarundinaria) in Thamnocalamus, while also recognizing other Chinese genera such as Yushania. However, this is still not very satisfactory, as Thamnocalamus and Fargesia can be clearly separated on a range of floral and vegetative characteristics. Other authorities (Keng f., 1957; Keng f., 1982a; Keng f., 1982b; Keng f., 1983; Yi, 1983) have adopted a much narrower generic concept, latterly recognizing both Fargesia and Yushania as well as many other smaller genera, and treating Sinarundinaria as a synonym of Fargesia. Campbell (1988) attempted a compromise between the different approaches, which resulted in the recognition of Sinarundinaria in two parts in addition to both Fargesia and Yushania, but circumscription of the smaller genera and groups became very difficult.

In an attempt to delimit Sino-Himalayan genera more satisfactorily a range of morphological characters have been considered. Previously reported studies (Stapleton, 1991) showed that characteristics of vegetative branching and sheathing were particularly useful at the generic level in these bamboos, and could be used to separate distinct groups of species, which matched several new genera recently described in the Chinese literature. Very close similarities were seen between Fargesia murielae and Sinarundinaria nitida in branching and prophyll characteristics, and consequently Sinarundinaria was treated as a synonym of Fargesia. This treatment was borne out when $S$. nitida eventually flowered, illustrating the predictive value of 

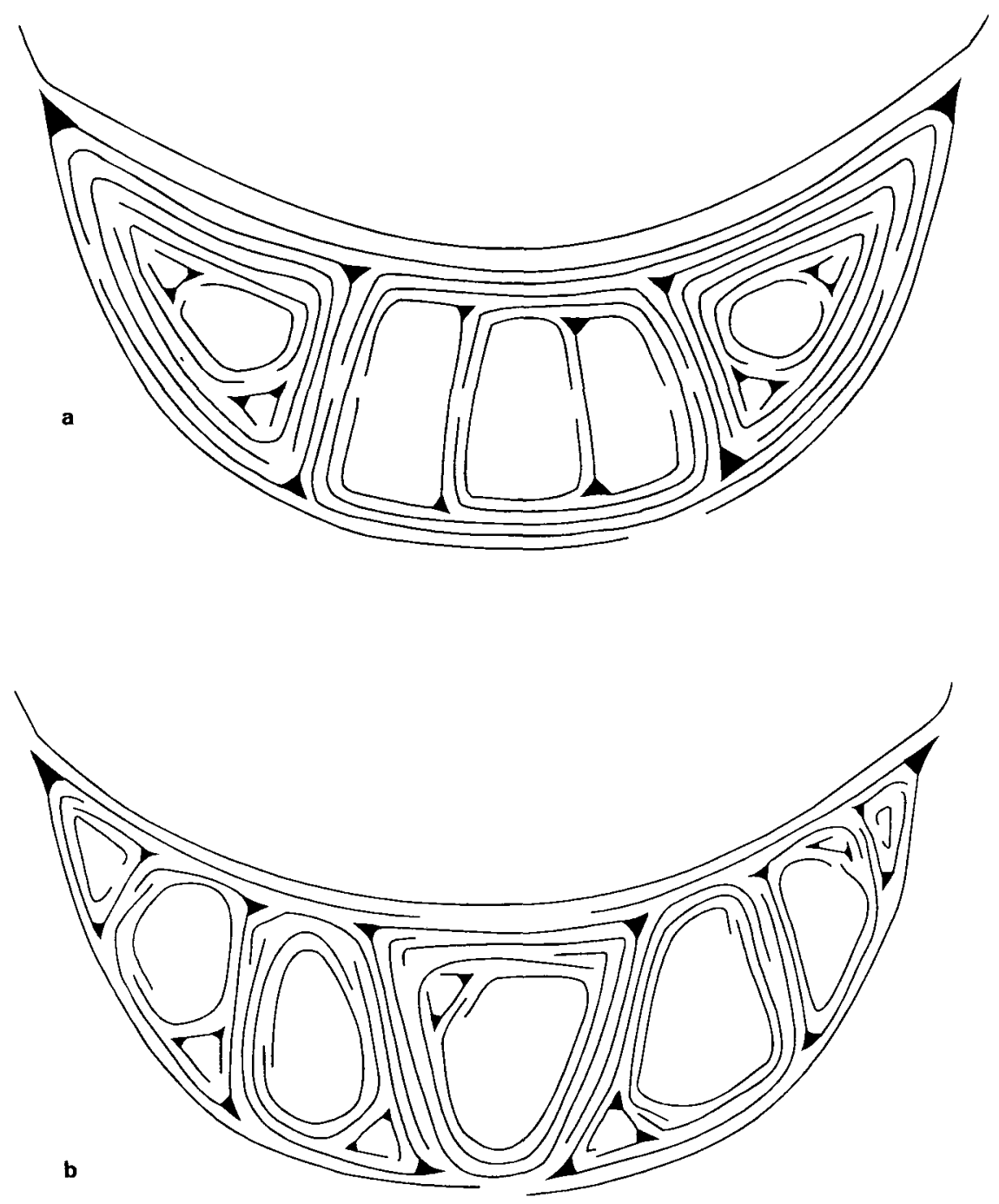

FIG. 1. Cross-sections of mid-culm buds showing differences in the width and keeling of prophylls and insertion of prophyllate branch axes with and without intervening sheaths (from Stapleton, 1991). a, Thamnocalamus spathiflorus, $\times 10 ; \mathrm{b}$, Borinda grossa, $\times 10$. 


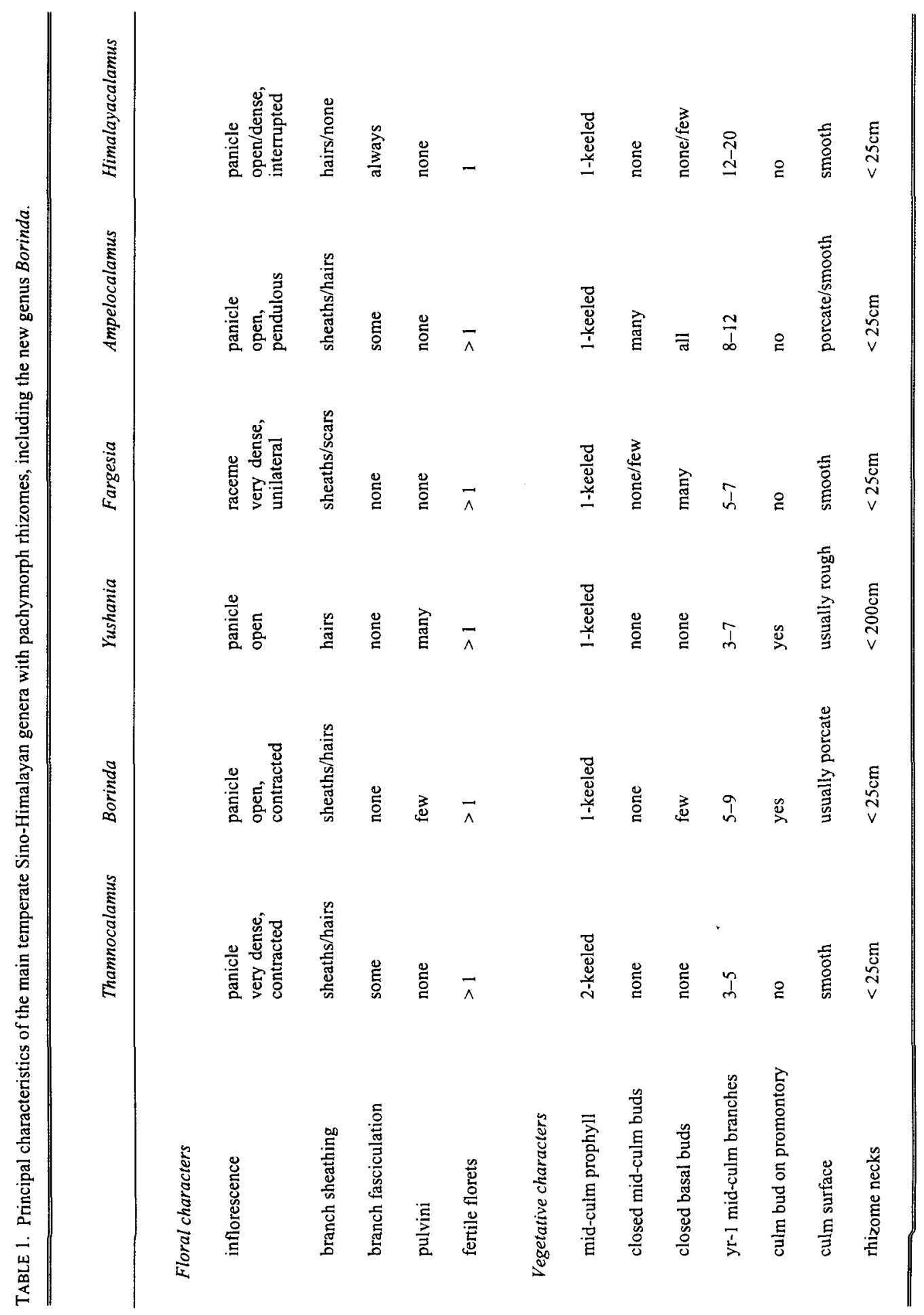


these vegetative characteristics at the generic level. Species of Thamnocalamus were seen to be clearly and unambiguously distinct from those of all the other 3-stamened Himalayan genera, including Fargesia. The mid-culm branch prophyll in Thamnocalamus has two keels (see Fig. 1a) and all branch axes are subtended by sheaths. In the type species of other genera such as Fargesia, Yushania and Sinarundinaria, the mid-culm branch prophyll has only one keel, and branch axes lack subtending sheaths (see Fig. 1b). Floral features such as degree of reduction of branches or sheaths subtending branching within the inflorescence, and presence of vestigial buds in glume axils, reinforced vegetative differences between Thamnocalamus and the other genera.

The genera that were distinguished clearly on a range of characters included Fargesia Franchet, Yushania Keng f., Ampelocalamus Chen, Wen, \& Sheng, Himalayacalamus Keng f., Drepanostachyum Keng f., and Neomicrocalamus Keng f. None of these genera were recognized by Clayton \&.Renvoize (1986) or Chao \& Renvoize (1989). In addition to those groups of species that can be placed satisfactorily within published genera, a further group of species can be distinguished on a range of floral and vegetative characteristics. These species have open paniculate inflorescences, similar to those of Yushania but with more bracts and fewer pulvini at points of inflorescence branching. Their rhizomes are shorter than those of Yushania species, and closer to those of Fargesia species, but the buds and branching are borne well above the nodal line on a projection similar to that described by McClure (1973) as a 'promontory' in species of Arthrostylidium Ruprecht. Basal culm buds are closed at the front while they are always open in Yushania. As no published genus appears appropriate for these species, the new genus Borinda is described. It includes several little-known Tibetan bamboos, for example Arundinaria macclureana Bor, and two new species from Nepal. The genus is named in honour of Dr N.L. Bor, the author of the first species described. The characteristics of Borinda and related genera are given in Table 1. Fargesia, as interpreted here, is not known from the Himalayas, apparently being confined to the mountains of central China.

\section{SYSTEMATIC TREATMENT}

The numbering of genera continues from Part I (Stapleton, 1994). All specimens cited are at K unless otherwise indicated. The abbreviation THIM has now been registered with the Index Herbariorum for the Forest Department Herbarium in Thimphu (previously referred to as THIMPHU).

Subtribe Arundinariinae Bentham, J. Linn. Soc. (Bot.) 19: 31 (1881).

Inflorescence semelauctant, bracts variously reduced or absent, spikelets sessile or pedicellate with prophyll represented by lower glume. Stamens 3. Rhizomes leptomorph or pachymorph.

7. Arundinaria Michaux in Fl. Bor. Am. 1: 73 (1803).

Type species: Arundinaria gigantea (Walter) Muhlenburg.

Frost-hardy bamboos from upper temperate zones. Stands diffuse, rhizomes leptomorph. Culms erect, surface smooth. Inflorescence semelauctant, a raceme or open panicle, often with 
pulvini but with little or no fasciculation. Panicle branches subtended by very small remnants of sheaths or rings of hairs, with branch prophylls represented by the lower glumes of pedicellate spikelets. Mid-culm branch buds enclosed by single 2-keeled prophylls, always open at the front. Lateral branch axes always subtended by sheaths. Basal culm buds open. Leaf venation strongly tessellated.

\section{GENERIC STATUS AND SEPARATION}

This genus has been gradually reduced by recognition of new genera to the point where it has been considered a monotypic North American genus (Keng \& Keng f., 1959), but the characteristics of the type species have been clearly defined (McClure, 1973), and it is difficult to see how some Asian genera such as Pleioblastus Nakai can be separated from it consistently. Arundinaria includes only one Himalayan species. The combination of leptomorph rhizomes, which can continue under the ground indefinitely, and tall 2-keeled mid-culm bud prophylls separate this genus from all other Himalayan genera.

\section{ENUMERATION OF SPECIES IN NEPAL AND BHUTAN}

1. Arundinaria racemosa Munro, Trans. Linn. Soc. London 26: 17 (1868).

Type: India, Darjeeling district, Birch Hill, viii 1857, Thomson s.n. (lecto. selected by Chao \& Renvoize 1989, K).

Syn.: Fargesia racemosa (Munro) Yi, J. Bamboo Res. 2(1): 39 (1983); Yushania racemosa (Munro) R.B. Majumdar in Karthikeyan, S. et al., Fl. In. Enumerat. - Monocot.: 283 (1989).

Representative specimens:

BHUTAN: Tongsa, Yotong La, Stapleton 852 (THIM); Thimphu, Dorchula, Stapleton 872 (THIM); Bumthang, Lame Gompa, Bürgi s.n. (THIM).

Distribution: West Bengal, Sikkim, and Bhutan.

8. Thamnocalamus Munro, Trans. Linn. Soc. London 26: 33 (1868).

Type species: Thamnocalamus spathiflorus (Trin.) Munro.

Frost-hardy bamboos from upper temperate zones. Clumps unicaespitose, rhizomes pachymorph with necks less than $25 \mathrm{~cm}$ long. Inflorescence semelauctant, a dense contracted racemose panicle or raceme, never unilateral, with occasional fasciculation and no pulvini, branches usually subtended by substantial sheaths or occasionally by rings of hairs, and prophylls on the branches represented by single-keeled sheaths inserted near the point of branching or as the lower glumes of pedicellate spikelets, which often subtend vestigial buds. Mid-culm branch buds enclosed by single 2-keeled prophylls, the front of all culm buds open, with lateral branch axes always subtended by sheaths, first-year branches usually 5 at the midculm nodes. Leaf venation strongly tessellated. 
HIMALAYAN TAXA

Three species of Thamnocalamus have been described from the Himalayas. The type species, T. spathiflorus (Trin.) Munro, was described from material collected by Wallich in Nepal in 1821. Munro (1868) included sterile material from north-western India and Sikkim under this species, albeit with reservations. Flowering material was later collected in north-western India and Sikkim by Gamble and others. Gamble (1896) considered the Himalayan material to represent two separate species. He assumed the Wallich 1821 type collection of spathiflorus had come from western Nepal, and cited it (Gamble, 1896), along with the material from northwestern India, under Arundinaria spathiflora Trin. He described a new species, Arundinaria aristata Gamble, from the material collected in Sikkim. However, it would appear that the Wallich 1821 type collection of $T$. spathiflorus is most likely to have been made in central rather than western Nepal. Firstly, Wallich could not leave the Kathmandu area (Burkill, 1953), and most of his collections and those of his collectors came from central Nepal. Secondly the Wallich 1821 type collection has oral setae on some of the leaves, while all Nepalese collections of $T$. spathiflorus from west of the Kathmandu Valley have leaf sheaths without oral setae. If this supposition is correct it would place the type collections of both T. spathiflorus and T. aristatus in the same subspecies. This is supported by further collections of material that was flowering at approximately the same time, clearly labelled E. Nepalia, with flowers apparently identical to the Wallich 1821 type material. These were presumably made in 1818 by Wallich's Kathmandu-based collectors prior to his own residence in Kathmandu. Therefore it would seem that Gamble was incorrect in placing Wallich's type material in a different species to material from Sikkim, and that Arundinaria aristata Gamble is a synonym of Thamnocalamus spathiflorus (Trin.) Munro. A third Himalayan species, Thamnocalamus falconeri Munro, is treated here as Himalayacalamus falconeri (Munro) Keng $f$.

Considerable variation in vegetative characteristics is encountered along the Himalayan distribution of Thamnocalamus. Three taxa are known to cover broad geographical areas and can be distinguished consistently on important vegetative characteristics. They are treated here as subspecies spathiflorus from central and eastern Nepal, Sikkim, and Bhutan, the new subspecies nepalensis from central and western Nepal, and the new subspecies occidentalis from north-western India. Although there are some minor differences between the flowers of these subspecies, such differences are obscured by the considerable variation found within each taxon, and it seems impossible to distinguish between their flowers consistently. Therefore all taxa described from the Himalayas are treated here as one species, Thamnocalamus spathiflorus (Trin.) Munro.

Two further taxa are known from localized areas. One has distinctive culm sheaths and culms, and is presently known only from central Bhutan. It is described here as a new variety, bhutanensis. Collections of Thamnocalamus spathiflorus from eastern Bhutan have not included culm sheaths, so the extent and status of this taxon are both uncertain at the present time. The other taxon was described as Fargesia crassinoda Yi from material collected in Tibet. It has also been collected from an adjacent area of Nepal, and plants are now in cultivation in Europe. Although its flowers are not known, the vegetative branching shows its affinity to Thamnocalamus rather than Fargesia. It is transferred and given new status here as T. spathiflorus var. crassinodus. It has only been found on the geographic boundary between the two 
subspecies, spathiflorus and nepalensis, and collections combine characteristics of both subspecies. Growth is vigorous and the culm nodes are swollen. The culm sheaths may be completely glabrous, or they may have light or dense bristles. Although leaf size is variable, several collections appear to have substantially smaller leaves than those of subspecies spathiflorus or nepalensis.

\section{ENUMERATION OF THE HIMALAYAN TAXA}

1. Thamnocalamus spathiflorus (Trin.) Munro, Trans. Linn. Soc. London 26: 34 (1868).

Type: Nepal [Central, near Kathmandu], Wallich 5041 (lecto. selected by Chao \& Renvoize $1989, \mathrm{~K})$.

Syn.: [Arundinaria procera Wall. in sched.] Arundinaria spathiflora Trin., Mém. Acad. Imp. Sci. Saint. Pétersbourg,

Sér. 6, Sci. Math., Seconde Pt. Sci. Nat. 1: 617 (1835).

Distribution: Himachal Pradesh to Eastern Bhutan.

\section{KEY TO SUBSPECIES AND VARIETIES OF T. SPATHIFLORUS}

1a. Culm nodes swollen, nodal diameter $>3 \mathrm{~mm}$ greater than that of internode, branching very strong var. crassinodus

1b. Nodal diameter $<3 \mathrm{~mm}$ greater than that of internode 2

2a. Culm sheath with dorsal bristles or bristle bases 3

2b. Culm sheath dorsally glabrous

3a. Culm sheath symmetrical or slightly asymmetrical subsp. spathiflorus

3b. Culm sheath strongly asymmetrical var. bhutanensis

4a. Leaf sheaths with oral setae, culm sheaths asymmetrical subsp. occidentalis

4b. Leaf sheaths without oral setae, culm sheaths symmetrical subsp. nepalensis

1a. subsp. spathiflorus

Syn.: Arundinaria aristata Gamble, Ann. Roy. Bot. Gard. (Calcutta) 7: 18 (1896); Thamnocalamus aristatus (Gamble) E.G. Camus, Les Bambusées: 54 (1913); Thamnocalamus spathiflorus subsp. aristatus (Gamble) McClintock, Moorea 4: 20 (1985). Type: India, Sikkim, Phalut, Gammie s.n. (lecto. selected by Chao \& Renvoize 1989, K).

Representative specimens:

NEPAL: E. Nepalia, 1818, Wallich's collectors s.n. (BM); Kathmandu, Daman, $27^{\circ} 36^{\prime} \mathrm{N} 85^{\circ} 04^{\prime} \mathrm{E}$, $2500 \mathrm{~m}$, Stapleton 363; Dolakha dist., Marbu, $27^{\circ} 50^{\prime} \mathrm{N} 86^{\circ} 21^{\prime} \mathrm{E}, 3200 \mathrm{~m}$, Stapleton 355; Milke Danda, Dap kharka, 2500m, Emery 140 (BM); ibid. Emery 141 (BM); Milke Danda, Zori Bhote, Emery 115 (BM); Sankhuwasabha dist., Hatia to Barun Khola, 9500ft, Beer 12303 (BM); Malinghini kharka, Kasua Khola, 2600m, Emery 24 (BM); Limbua Khola, $27^{\circ} 30^{\circ} \mathrm{N} 87^{\circ} 57^{\prime} \mathrm{E}$, Williams 
932 (BM); Sankhuwasabha dist., Balutar, $27^{\circ} 38^{\prime} \mathrm{N} 87^{\circ} 18^{\prime} \mathrm{E}, 2450 \mathrm{~m}$, Emery 45 (BM, K); Sankhuwasabha dist., Barun khola, $27^{\circ} 42^{\prime} \mathrm{N} 87^{\circ} 18^{\prime} \mathrm{E}, 2450 \mathrm{~m}$, Emery 209 (BM, K).

BHUTAN: Thimphu, Dorchula, $27^{\circ} 29^{\prime} \mathrm{N} 89^{\circ} 46^{\prime} \mathrm{E}, 3100 \mathrm{~m}$, Stapleton 871 (THIM).

Local name: rato nigalo (Nepali).

Distribution: Central Nepal to Western Bhutan.

1b. subsp. nepalensis Stapleton, subsp. nov.

A subsp. spathifloro vaginis culmorum glabris et eis foliorum sine setis oralibus differt. Type: Nepal, Kaski district, Karuwa, Pipar, $28^{\circ} 26^{\prime} \mathrm{N} 83^{\circ} 57^{\prime} \mathrm{E}, 3400 \mathrm{~m}, 15$ xi 1983, Stapleton 308 (holo. E).

Representative specimens:

NEPAL: Kaski dist., Deorali, 9600ft, [28 $\left.23^{\prime} \mathrm{N} 83^{\circ} 46^{\prime} \mathrm{E}\right]$, Sayers 2378 (BM); Rasuwa dist., Gosainkund, Ghopte, $3460 \mathrm{~m}$, McBeath 2233 (cult. E).

TIBET: Nyalam, $28^{\circ} 11^{\prime} \mathrm{N} 86^{\circ} 00^{\prime} \mathrm{E}, 3700 \mathrm{~m}$, Stapleton 892.

Local name: jarbutto (Nepali).

Differing from the type subspecies in its glabrous culm sheaths and its leaf sheaths without oral setae.

Distribution: Western zones of Nepal to Gosainkund and adjacent Tibetan valleys.

1c. subsp. occidentalis Stapleton, subsp. nov.

Thamnocalamo spathifloro Munro subsp. spathifloro similis, sed vaginis culmorum glabris asymmetricis, pilis callorum vaginarum foliorum brevioribus differt.

Type: India, Uttar Pradesh, Kedarkanda, 9000ft, vi 1893, Gamble 24341 (holo. K).

Representative specimens:

INDIA: Himachal Pradesh, Narkanda [Simla], 9500ft, Gamble 6075A (K); Simla, 8 vi 1849, Thomson s.n. (E).

Local name: ringal.

Similar to Thamnocalamus spathiflorus subsp. spathiflorus, but differing in its glabrous asymmetrical culm sheaths, and shorter hairs on the leaf sheath callus (outer ligule).

Distribution: North-western Himalayas of Himachal Pradesh and Uttar Pradesh.

1d. var. bhutanensis Stapleton, var. nov.

A varietate typica vaginis culmorum asymmetricis, internodiis culmorum juventorum dense ceraceis differt.

Type: Bhutan, Gasa district, Koena, $28^{\circ} 00^{\prime} \mathrm{N} 89^{\circ} 44^{\prime} \mathrm{E}, 3200 \mathrm{~m}, 12$ xi 1988, Stapleton 804 (holo. THIM).

Representative specimens:

BHUTAN: Gasa, Koena, $28^{\circ} 00^{\prime} \mathrm{N} 89^{\circ} 44^{\prime} \mathrm{E}, 3200 \mathrm{~m}$, Stapleton 803 (THIM); Tongsa, Yotong La, $27^{\circ} 32^{\prime} \mathrm{N} 90^{\circ} 36^{\prime} \mathrm{E}, 3300 \mathrm{~m}$, Stapleton 851 (THIM); Tashigang dist., Donga La [27 $35^{\prime} \mathrm{N} 91^{\circ} 20^{\prime} \mathrm{E}$,

Ludlow, Sherriff \& Hicks 20531 (BM, E)?

Local name: hum (Dzongkha).

Differs from the type variety in its asymmetrical culm sheaths and the densely waxy internodes of young culms.

Distribution: Central and possibly also Eastern Bhutan. 
1e. Thamnocalamus spathiflorus (Trin.) Munro var. crassinodus (Yi) Stapleton, comb. et stat. nov.

Basionym: Fargesia crassinoda Yi, J. Bamboo Res. 2(2): 24 (1983).

Type: Tibet, Gyirong Xian, Zheng Xing, $2900 \mathrm{~m}, L i \& D a 1$ (holo. in Herb. Forestry School of Sichuan Province) n.v.

Representative specimens:

NEPAL: Rasuwa dist., Langtang, Gore Tabela, 3450m, Stapleton 326; Langtang, Polunin 416 (BM, E); ibid. Polunin 1618 (BM); ibid. Edwards s.n. (cult. E).

Local name: ghunre nigalo (Nepali).

Distribution: Gyirong county in Tibet and Langtang Valley in Nepal.

\section{Borinda Stapleton, gen. nov.}

Fargesiae Franchet similis, sed inflorescentiis paniculatis laxis, ramificationibus inflorescentiarum piliferis interdum pulvinos ferens, marginibus gemmarum culmorum anticis plerumque non connatis, statura grandi, ramis pluribus supra nodos insertis differt. Ab Yushania Keng f. rhizomatibus brevioribus, paniculis magis contractis distinguitur.

Similar to Fargesia Franchet, but differing in its loose paniculate inflorescences with hairs and sometimes pulvini at the points of branching, margins of the buds usually not fused at the front, and greater number of branches, inserted above the nodes. To be distinguished from $Y u$ shania Keng $f$. by the shorter rhizomes and the more contracted panicles.

Type species: Borinda macclureana (Bor) Stapleton.

Frost-hardy bamboos from middle to upper temperate zones. Clumps unicaespitose, rhizomes pachymorph with solid necks less than $30 \mathrm{~cm}$ long, culms basally curving when rhizome necks are long, surface usually finely ridged. Inflorescence semelauctant, an open more or less contracted panicle, branches single with no fasciculation and few pulvini, branching subtended by very small remnants of sheaths or rings of hairs, and prophylls on the branches represented by single-keeled sheaths inserted near the point of branching or as the lower glumes of pedicellate spikelets. Culms unarmed. Mid-culm branch buds inserted above node on small raised promontory, enclosed by two single-keeled bracts, the front of the buds open, with lateral branch axes replicated without subtending sheaths, usually giving 7 branches at the mid-culm nodes in the first year. Basal 1-4 culm buds closed at front by fusion of margins. Leaf venation strongly tessellated.

\section{PREVIOUSLY DESCRIBED SPECIES}

Bor (1958) described Arundinaria macclureana from material collected in Tibet, and this species is now chosen as the type species of the new genus Borinda. Five species of Fargesia described by Yi (1983) from sterile Tibetan material collected in areas substantially to the east of Bhutan and Nepal are also considered here to be members of this genus. Several of these species seem to overlap morphologically, but a sound revision must await further fieldwork and collection of flowering material in Tibet. No species with characteristics of Borinda have hitherto been described from within Nepal, Sikkim, or Bhutan. 


\section{SPECIES ENCOUNTERED IN NEPAL AND BHUTAN}

Three species of Borinda have been encountered in Nepal and Bhutan. Two are clearly distinct from the species described from Tibetan material: Borinda chigar from western Nepal, and Borinda emeryi from eastern Nepal. Both these new species seem to be localized and they are of little importance in the rural economy. The third species, Borinda grossa (Yi) Stapleton, is common across central Bhutan, where it is a very important minor forest product, widely harvested from the forest and also cultivated for production of roof mats and fences.

Borinda grossa is similar to $B$. macclureana and also to two species known only from Tibet, and here transferred to Borinda, B. glabrifolia and $B$. setosa. The glumes and paleas of $B$. grossa are longer and more pubescent than those of $B$. macclureana, with margins and keels that are more ciliate, and they are arranged in longer, more flattened spikelets. Leaf sheath auricles are scarce to absent in $B$. grossa, while $B$. macclureana has prominent auricles. The oral setae of $B$. grosis $a$ are glabrous, while those of $B$. macclureana are densely scabrous. Unfortunately the culm sheaths of $B$. macclureana and the flowers of $B$. glabrifolia and $B$. setosa have not been collected. More comprehensive collections of Tibetan material are required before the correct status of these taxa can be decided upon. Munro wrote the name 'Thamnocalamus bhotanica' on a Griffith collection of $B$. grossa from Bhutan, but cited the specimen under Thamnocalamus spathiflorus (1868). Yi used two infertile specimens collected in Tibet to describe the species (as Fargesia grossa), relating it to Arundinaria racemosa Munro (as Fargesia racemosa (Munro) Yi). A flowering specimen found in Bhutan in 1986 is described below.

Borinda emeryi is more clearly distinct from all the Tibetan species, having glabrous culm sheaths and narrower florets. Collections had been determined (Chao \& Renvoize, 1989) as Sinarundinaria pantlingii (Gamble) Chao \& Renvoize (Yushania pantlingii (Gamble) Majumdar). It has persistent wax covering the entire culm internode, which becomes black with age. Leaf sheaths and branchlets also become very dark from exposure to frost. This leads to the local name 'black bamboo'. Present collections are inadequate for detailed illustration.

Borinda chigar is an unusual and interesting species found initially on the southern flank of the Annapurna massif in western Nepal (Stapleton \& Tamrakar, 1983). The specific epithet is based upon its vernacular name in Kaski district. It is distinctly different from all other Himalayan species in its extraordinarily long ligules on both culm and leaf sheaths. The bud characters seem to place it in Borinda, but only very small buds have been collected and its flowers are not known. It also differs from all the Himalayan species known so far in having delicate culm sheaths without clearly defined blades, very small branches and extremely narrow leaves. The culms sweep outwards at the base, giving an open form of clump.

\section{KEY TO BORINDA SPECIES FROM NEPAL AND BHUTAN}

1a. Clumps open, culms curving at base B. chigar

1b. Clumps dense, culms upright at base 2

2a. Culm sheaths glabrous B. emeryi

2b. Culm sheaths with dense bristles or bristle bases B. grossa 


\section{ENUMERATION OF SPECIES FROM NEPAL, BHUTAN, AND TIBET}

\section{Borinda chigar Stapleton, sp. nov. Fig. 2.}

Species ligulis longissimis laminis angustis culmis basaliter sursum curvatis vaginis culmorum tenuis a speciebus aliis Borindae cognitis bene distincta. Inflorescentia ignota.

Type: Nepal, Kaski district, Karuwa to Pipar, $28^{\circ} 24^{\prime} \mathrm{N} 83^{\circ} 58^{\prime} \mathrm{E}, 3000 \mathrm{~m}, 16$ xi 1983, Stapleton 315 (holo. E).

Representative specimen:

NEPAL: Dhading dist., Tibling, $28^{\circ} 10^{\prime} \mathrm{N} 85^{\circ} 09^{\prime} \mathrm{E}$, Baker, Miller, \& Burkitt 47 (K).

Local name: chigar (Nepali).

Well distinguished from all the known species of the genus by its very long ligules, its narrow leaves, its basally upward-curving culms and its thin culm sheaths. Inflorescence not known.

Clumps open. Rhizome pachymorph, up to $30 \mathrm{~cm}$ long, solid. Culms apically drooping, basally curving outwards and upwards; height up to $4 \mathrm{~m}$; at $\mathrm{c} .50 \mathrm{~cm}$ above ground diameter up to $1.5 \mathrm{~cm}$, walls up to $2 \mathrm{~mm}$ thick; nodes slightly raised, persistent sheath base lightly whitepubescent at first, unarmed; maximum internode length $15 \mathrm{~cm}$; surface with very dense white wax over entire internode, culm remaining dull. New culm sheath from $\mathrm{c} .50 \mathrm{~cm}$ above ground c. $75 \mathrm{~mm}$ wide at base, height to ligule $\mathrm{c} .27 \mathrm{~mm}$, attenuating triangularly from base; upper $1 / 2$ membranous, disintegrating rapidly, transverse veinlets prominent; blade always erect, $\mathrm{c} .3 \mathrm{~cm}$ long $\times 5 \mathrm{~mm}$ wide, very persistent, interior very shortly pubescent beside ligule; hairs scattered to quite dense, erect, clear, with bulbous bases; shoulders and auricles absent, blade continuous with sheath; oral setae absent; ligule triangular to subulate, margin sparsely ciliate or penicillate; upper $1 / 2$ of both edges with rather sparse, stout, brittle cilia $<1 \mathrm{~mm}$ long. New leaf sheath surface glabrous, margins glabrous; callus (outer ligule) not pronounced, with cilia up to $1 \mathrm{~mm}$ long; auricles none; shoulders rising very steeply, shortly ciliate; oral setae none; ligule extremely long, up to $5 \mathrm{~mm}$, glabrous, ragged. Leaf blade up to $110 \mathrm{~mm}$ long $\times 6 \mathrm{~mm}$ wide; abaxial and adaxial surfaces glabrous and glaucous; petiole glabrous, narrow, long; tessellation distinct, but transverse veinlets well spaced out; base attenuate. Branches small, from elliptical buds with broad, rounded wings; central branch up to $1 \mathrm{~mm}$ in diameter with no aerial roots. Inflorescence not known.

Distribution: Apparently endemic to central and western Nepal.

\section{Borinda emeryi Stapleton, sp. nov.}

Borindae macclureanae (Bor) Stapleton affinis, sed lemmatibus fertilis gracilioribus, ad margines breviter pubescentibus vel glabris, vaginis culmorum fere glabris, eis foliorum sine setis oralibus, differt.

Type: Nepal, Sankhuwasabha district, Younglay, $27^{\circ} 44^{\prime} \mathrm{N} 87^{\circ} 12^{\prime} \mathrm{E}$, 10 vii 1974 , Emery 54 (holo. K, iso. E).

Representative specimens:

NEPAL: Sankhuwasabha dist., Dore, $27^{\circ} 43^{\prime} \mathrm{N} 87^{\circ} 16^{\prime} \mathrm{E}$, Emery $10(\mathrm{~K})$; Sankhuwasabha dist., Barun Khola, $27^{\circ} 37^{\prime} \mathrm{N} 87^{\circ} 14^{\prime} \mathrm{E}$, Long et al. EMAK 276 (E); ibid. $27^{\circ} 44^{\prime} \mathrm{N} 87^{\circ} 12^{\prime} \mathrm{E}$, Long et al. EMAK 381 (E); ibid. $27^{\circ} 45^{\prime} \mathrm{N} 87^{\circ} 16^{\prime} \mathrm{E}$, Long et al. EMAK 682 (E); Manibhanjyang, Milke Danda, Chainpur dist., $27^{\circ} 12^{\prime} \mathrm{N} 87^{\circ} 28^{\prime} \mathrm{E}$, Long et al. EMAK 945 (E); ibid. Long et al. EMAK 967 (E); Sankhuwasabha dist., Barun Khola, Yangle pasture, $3700 \mathrm{~m}$, Wraber et al. 34654 (BM, LJU). 

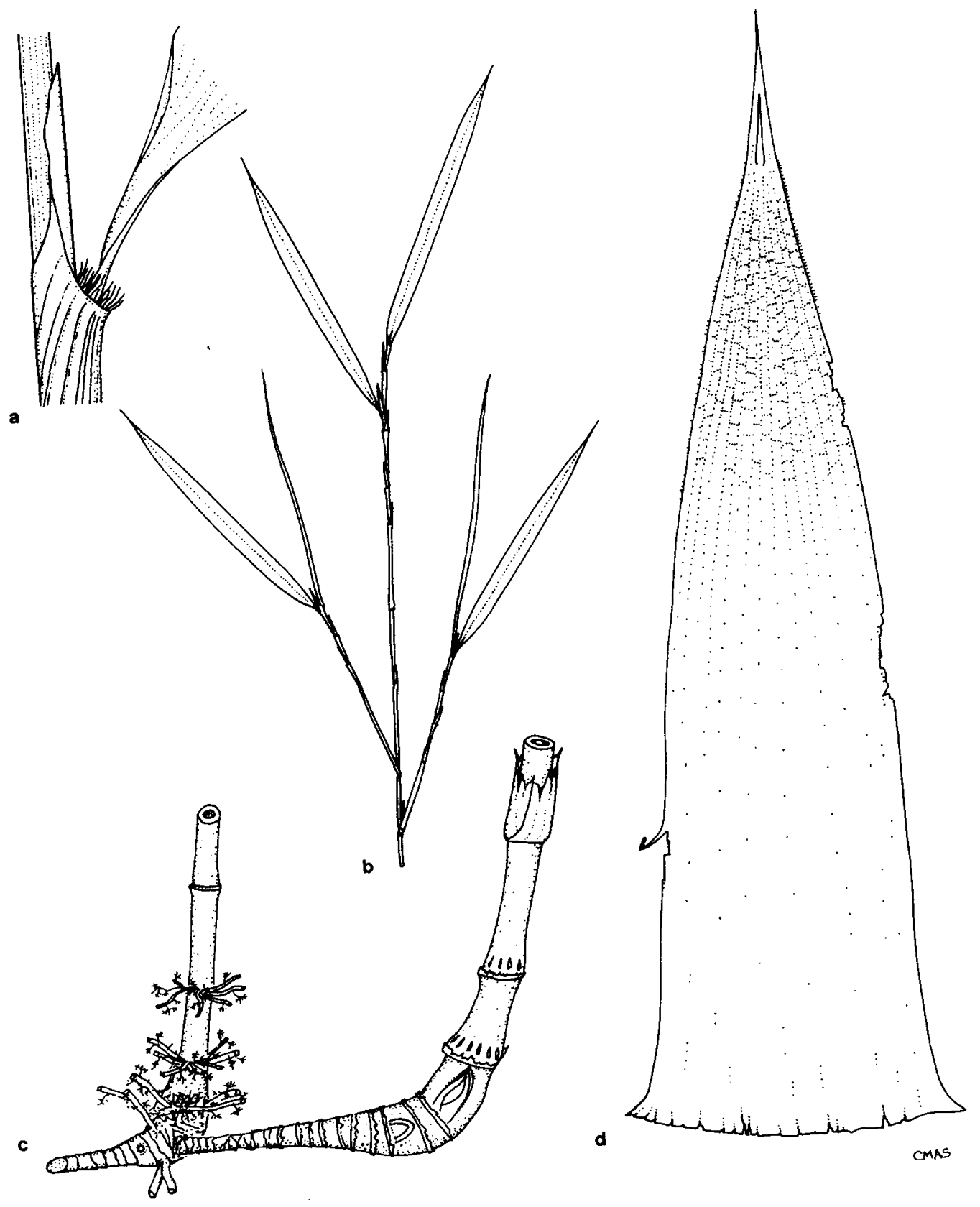

FIG. 2. Borinda chigar. a, leaf sheath apex, $\times 10$; b, leaves, $\times 0.5$; c, rhizomes, $\times 0.4 ; \mathrm{d}$, culm sheath, $\times 0.5$. 
Local name: kalo nigalo (Nepali).

Similar to Borinda macclureana but with nearly glabrous culm sheaths, leaf sheaths without oral setae, and narrower glumes shortly pubescent or glabrous towards their margins.

Clumps probably dense. Rhizomes pachymorph, probably c. $20 \mathrm{~cm}$ long. Culms up to $4 \mathrm{~m}$ tall; nodes scarcely raised, unarmed, glabrous, internodes finely ridged and uniformly waxy, the wax becoming black. Culm sheaths glabrous, or apically very shortly pubescent to sparsely scabrous; persistent base thickened and glabrous; auricles rounded, c. $1 \mathrm{~mm}$, reflexed or erect, pubescent; oral setae absent; ligule 1-2mm tall, shortly ciliate, pubescent; blade persistent, $2-10 \mathrm{~cm}$ long, $3-5 \mathrm{~mm}$ wide, erect or reflexed, adaxial proximally shortly pubescent. Leaf sheaths glabrous; margins glabrous; callus (outer ligule) not pronounced, very shortly ciliate; no auricles or oral setae; shoulders very shortly ciliate; ligule c. $1.5 \mathrm{~mm}$ long, glabrous, truncate; blade glabrous or abaxial sparsely pilose at first, c.7-9cm long, $6-8 \mathrm{~mm}$ wide. Inflorescence semelauctant, a panicle usually with rings of hairs subtending ultimate branches rather than reduced sheaths; pedicels up to $2 \mathrm{~cm}$; pulvini absent. Spikelets up to $40 \mathrm{~mm}$ long, with 2 empty glumes and up to 6 fertile florets, terminating in an incomplete floret. Lower empty glume 6-11 mm long, glabrous with a very shortly scabrous awn. Upper empty glume similar, $8-14 \mathrm{~mm}$ long. Fertile lemma $13-17 \mathrm{~mm}$ long, very shortly pubescent all over or glabrous near margins, tip scabrous. Palea $10-12 \mathrm{~mm}$ long, tip bifid for at least $1 \mathrm{~mm}$ and scabrous; keels proximally glabrous, distal $1 / 2$ with c. $0.3 \mathrm{~mm}$ cilia. Rhachilla segments $5-6 \mathrm{~mm}$ long, flattened, puberulent, with ring of c. $0.5 \mathrm{~mm}$ cilia at apices. Stigmas 2-3. Anthers yellow, bifid or blunt, not penicillate; pollen yellow. Lodicules 3 , similar, with c. $0.5 \mathrm{~mm}$-long cilia.

Distribution: Apparently endemic to East Nepal.

3. Borinda extensa (Yi) Stapleton, comb. nov.

Basionym: Fargesia extensa Yi, J. Bamboo Res. 2(2): 27 (1983).

Type: Tibet, Medog Xian, 2200-2500m, Yi 77177 (holo. in Herb. Forestry School of Sichuan Province) n.v.

4. Borinda farcta (Yi) Stapleton, comb. nov.

Basionym: Fargesia farcta Yi, J. Bamboo Res. 2(2): 30 (1983).

Type: Tibet, Cona Xian, 2300m, Zha 1 (holo. in Herb. Forestry School of Sichuan Province) n.v.

5. Borinda glabrifolia (Yi) Stapleton, comb. nov.

Basionym: Fargesia glabrifolia Yi, J. Bamboo Res. 2(2): 32 (1983).

Type: Tibet, Cona Xian, 3100-3500m, Jiang 3 (holo. in Herb. Forestry School of Sichuan Province) n.v.

\section{Borinda grossa (Yi) Stapleton, comb. nov.}

Borindae macclureanae (Bor) Stapleton affinis, sed omnibus partibus grandibus, glumis et lemmatibus longioribus brevius pubescentibus, vaginis foliorum exauriculatis, setis oralibus vaginarum foliorum glabris differt. 
Type: Tibet, Cona Xian, 2600m, Jiang 2 (holo. in Herb. Forestry School of Sichuan Province) n.v.

Syn.: [Thamnocalamus bhotanica Munro in sched.]

Fargesia grossa Yi, J. Bamboo Res. 2(2): 35 (1983).

[Fargesia bhutanensis Stapleton, unpublished $\mathrm{PhD}$ thesis, University of Aberdeen: 127 (1991)].

Representative specimens:

BHUTAN: Bumthang, Rudong La, $27^{\circ} 35^{\prime} \mathrm{N} 90^{\circ} 57^{\prime} \mathrm{E}, 9-10,500 \mathrm{ft}$, Griffith Itin. 689 (K); Tongsa dist., Yuto $\mathrm{La}$ (W.), $27^{\circ} 31^{\prime} \mathrm{N} 90^{\circ} 34^{\prime} \mathrm{E}, 3000 \mathrm{~m}$, Grierson \& Long 1159 (E); Tongsa dist., Dorji Gompa, $27^{\circ} 29^{\prime} \mathrm{N} 90^{\circ} 35^{\prime} \mathrm{E}, 3000 \mathrm{~m}$, Stapleton 854 (THIM); Tongsa district, Nobding, $27^{\circ} 34^{\prime} \mathrm{N}$ $90^{\circ} 10^{\prime} \mathrm{E}, 2700 \mathrm{~m}$, Stapleton 867 (THIM); Tongsa dist, Dorji Gompa, $27^{\circ} 29^{\prime} \mathrm{N} 90^{\circ} 35^{\prime} \mathrm{E}, 3000 \mathrm{~m}, 21$ ix 1986, Stapleton 412 (THIM).

TIBET: Cona Xian, 2600m, 13 x 1977, Jiang No. A (Herb. Forestry School of Sichuan Province).

Local name: rhui (Tongsa dialect), baa (Dzongkha).

Similar to Borinda macclureana but larger, with longer glumes and paleas, both with shorter pubescence, leaf sheaths without auricles, oral setae on the leaf sheaths glabrous.

Clumps dense. Rhizomes pachymorph, up to $30 \mathrm{~cm}$ long, solid. Culms drooping, maximum length $10 \mathrm{~m}$; at $\mathrm{c} .50 \mathrm{~cm}$ above ground maximum diameter $4.5 \mathrm{~cm}$, walls up to $5 \mathrm{~mm}$ thick, nodes not substantially raised, unarmed; maximum internode length $50 \mathrm{~cm}$; surface finely ridged, \pm wax, entire internode often covered with wax, new culms often strongly glaucous and densely waxy below nodes. New culm sheath from $c .50 \mathrm{~cm}$ above ground up to $12 \mathrm{~cm}$ wide at base, attenuating triangularly and convexly to a width of up to $1 \mathrm{~cm}$ at the neck, persistent till branching; height to ligule c.26cm; bristles scattered, deciduous, brown, bulbous-based, antrorsely erect, c. $1 \mathrm{~mm}$ long; blade decurrent, erect at tip of new shoot, up to $70 \mathrm{~mm}$ long, c. $2 \mathrm{~mm}$ wide, lightly covered with c. $0.5 \mathrm{~mm}$ deciduous bristles, edges scabrous, quickly deciduous; base pubescent or pilose with ring of slender 2-3mm light brown hairs; shoulders with c. $0.2 \mathrm{~mm}$ cilia, bearing setae at edges; auricles absent on basal sheaths to very small at shoot apex; oral setae 6-10 each side, 3-8mm long, thick, erect, straight, honey-brown, glabrous with fine spiralling striations, extending onto edges of sheaths near culm base; ligule $1-2 \mathrm{~mm}$ long, shortly fimbriate, densely $0.3-0.5 \mathrm{~mm}$ pubescent, concave or truncate, or convex and asymmetrical at culm base with one end extending down the sheath margin; edges with c. $1 \mathrm{~mm}$-long cilia, overlapping edge ciliate to base, distal $1 / 4$ of inner edge ciliate, cilia merging with oral setae on sheaths from base of culm. New leaf sheath with light c. $1 \mathrm{~mm}$-long pubescence at first (proximal sheaths) or glabrous (distal sheaths); margins glabrous; callus (outer ligule) not pronounced, but with prominent cilia up to $1 \mathrm{~mm}$ long and initially cinnamon-coloured at the edges and c. $0.2 \mathrm{~mm}$ long and white at the centre; auricles absent or minute; shoulders with c. $0.1 \mathrm{~mm}$-long cilia; oral setae $2-5$ each side, wavy, erect, glabrous, $3-5 \mathrm{~mm}$ long and often fused at the base; ligule $15-25 \mathrm{~mm}$ long, c. $0.1 \mathrm{~mm}$ puberulent, truncate. Leaf blade $4.5-18(-26) \mathrm{cm}$ long, breadth $5-20(-25) \mathrm{mm}$; abaxial lightly to densely and persistently pilose all over with c. $1 \mathrm{~mm}$-long soft hairs, adaxial glabrous; petiole abaxial with dense c.1mm-long hairs, adaxial proximally pubescent with $<0.3 \mathrm{~mm}$ hairs; tessellation distinct. Branch buds present at all nodes, $1.5-3 \mathrm{~cm}$ tall, narrow, above $2-5 \mathrm{~mm}$-long swelling; basal bud dorsally and ventrally closed; mid-culm branches 5-7 in first year, up to 16 branches later; central branch up to $3 \mathrm{~mm}$ in diameter, with no aerial roots. Inflorescence semelauctant, a panicle usually with rings of hairs subtending 
ultimate branches rather than reduced sheaths; pedicels up to $3 \mathrm{~cm}$; pulvini scarce. Spikelets up to $55 \mathrm{~mm}$ long, with 2 empty glumes, up to 10 fertile florets, and terminating in an incomplete floret. Lower empty glume $9-15 \mathrm{~mm}$ long, glabrous, with very shortly scabrous awn. Upper empty glume $13-17 \mathrm{~mm}$ long, glabrous, with a very shortly scabrous awn. Occasional reduced buds in empty glume axils. Fertile lemma $15-20 \mathrm{~mm}$ long, puberulent but with longer hairs of up to $0.7 \mathrm{~mm}$ near margins, tip scabrous. Palea $10-12 \mathrm{~mm}$ long, apex acute or $<1 \mathrm{~mm}$ bifid; tip shortly ciliate; distal $1 / 2$ and tip of keels with c. $3 \mathrm{~mm}$ cilia. Rhachilla segments $4-6 \mathrm{~mm}$ long, flattened, puberulent with longer hairs of c.0.7mm at apices. Stigmas 2-3. Anthers c. $9 \mathrm{~mm}$ long, yellow; tips slightly purple, blunt or penicillate, not bifid. Lodicules 3 , similar, with cilia of c. $1 \mathrm{~mm}$.

Distribution: Tibet (Cona Xian), central and eastern Bhutan.

7. Borinda macclureana (Bor) Stapleton, comb. nov.

Basionym: Arundinaria macclureana Bor, Kew Bull. 12(3): 420 (1958).

Type: Tibet, Kongbo, Molo, valley of Lilung Chhu, 3500m, Ludlow, Sherriff, \& Taylor 4395 (lecto. chosen by Stapleton 1993, BM).

Syn.: Fargesia macclureana (Bor) Stapleton, Bamboo Soc. Newsl. 17: 17 (1993); Sinarundinaria macclureana (Bor) G.Y. Yang \& C.S. Chao, J. Bamboo Res. 13(1): 20 (1993).

8. Borinda setosa (Yi) Stapleton, comb. nov.

Basionym: Fargesia setosa Yi, J. Bamboo Res. 2(2): 43 (1983).

Type: Tibet, Bomi Xian, 2700-3800m, Yi 77126 (holo. in Herb. Forestry School of Sichuan Province) n.v.

10. Yushania Keng f., Acta Phytotax. Sin. 6(4): 355 (1957).

Type species: Yushania niitakayamensis (Hayata) Keng $\mathrm{f}$.

Syn.: Butania Keng f., J. Bamboo Res. 1(2): 41 (1982). Type: B. pantlingii (Gamble) Keng f.

Frost-hardy bamboos from middle to upper temperate zones. Stands diffuse, rhizomes pachymorph with necks up to $2 \mathrm{~m}$ long. Culms basally erect, surface often scabrous, usually not ridged. Inflorescence semelauctant, an open panicle, often with pulvini but with little or no fasciculation. Panicle branches subtended by very small remnants of sheaths or rings of hairs, with branch prophylls represented by the lower glumes of pedicellate spikelets. Mid-culm branch buds inserted above node on small raised promontory, enclosed by two single-keeled bracts, always open. Lateral branch axes replicated without subtending sheaths. Basal culm buds open at front. Leaf venation strongly tessellated.

\section{GENERIC STATUS AND SEPARATION}

This genus was established specifically for temperate bamboos with widely spreading habit but pachymorph rhizomes. It is now universally accepted that these species are clearly separated 
from the genus Arundinaria, which has leptomorph rhizomes that can continue underground growth indefinitely, and is represented in the Himalayas by a single species, $A$. racemosa Munro.

Keng (1982b) described a new genus, Butania, with type species Butania pantlingii (Gamble) Keng f., described from material collected in Sikkim. This was keyed out (Keng f., 1982a) from Yushania and Fargesia on the assumption that, like Chimonocalamus and Chimonobambusa, it has thorns and 3 branch buds at each culm node. This may have been because of Gamble's suggestion (Gamble, 1896) that his Arundinaria pantlingii might turn out to be close to the thorny, clump-forming species from Meghalaya and Sikkim, Chimonocalamus griffithianus (Munro) Hsueh \& Yi. Gamble (1912) re-iterated that his $A$. pantlingii might be thorny at the nodes, but the collections of $A$. pantlingii from Sikkim have no evidence of thorns whatsoever, and they clearly have more than three branches. The flowers are very close to those of Yushania maling, with the large inflorescence pulvini seen in many Yushania species, and Majumdar (1989) in his enumeration of Indian bamboos transferred this species to Yushania. Collections of $A$. pantlingii from Sikkim do not include rhizomes, but the bamboo tentatively identified as Yushania pantlingii in eastern Bhutan has spreading, long-necked pachymorph rhizomes, similar to those of Yushania hirsuta. Gamble cultivated his Arundinaria pantlingii at his house in Hampshire from material sent from the Lloyd Botanic Garden in Darjeeling, and describing it in a letter he sent to Kew in 1921, attached to a collection (Gamble 30867, K), he stated that 'it must have plenty of room as the rhizomes are long and send up shoots at intervals so that it does not form clumps'. Thorns were not mentioned at all. Therefore it would seem quite certain that Yushania is the appropriate genus for this species, although further fieldwork is still required to investigate all the bamboos found by Pantling's collectors on the Rechi La in Sikkim in September 1895. Unfortunately this locality is in a sensitive border area, and it is not likely that foreigners will be allowed to visit it. Arundinaria pantlingii is likely to flower there in A.D. 2005, having a well-documented flowering cycle of around 36 years.

Three other species now placed in Yushania were also initially described by Gamble (1896): A. hirsuta, A. microphylla, and A. rolloana. A further species, Arundinaria maling Gamble, was separated from Arundinaria racemosa Munro at a later date (Gamble, 1912). With the exception of $A$. maling these species were only briefly described and have remained largely unknown. The Chinese literature includes two further binomials based upon material from Tibet, $Y$. xizangensis $\mathrm{Yi}$, and $Y$. yadongensis $\mathrm{Yi}$ (with which Y. longissima $\mathrm{Yi}$ nom. illeg. is synonymous).

\section{SPECIES ENCOUNTERED IN NEPAL AND BHUTAN}

Four species have been encountered so far in Nepal and Bhutan. Yushania hirsuta and Y. pantlingii are large, vigorous species that often form dense, impenetrable thickets, and can suppress tree regeneration if clear-felling removes the canopy completely. They are resilient bamboos with rhizomes that penetrate to considerable depth. They occupy ecologically similar habitats and survive in what are, for bamboos, relatively dry sites. They have few uses and can be categorized as pernicious weeds. Yushania rolloana (Gamble) Yi from Nagaland is very similar to $Y$. hirsuta, and may be synonymous, but its flowers are not known. 
Yushania maling and $Y$. microphylla are species of smaller stature. $Y$. maling is a common component of the temperate forest understorey in eastern Nepal and southern Bhutan. In western Bhutan some plants have a ring of light hairs at the base of the culm sheath, smoother culms, thinner culm walls, proximal leaf sheaths with ciliate edges, and larger leaf sheath auricles. Y. microphylla is a similar species, but has hollow rhizomes, which may allow it to succeed on flatter and wetter sites than other Yushania species. It forms large areas of pastureland in central Bhutan as well as occurring in the forest understorey. It is often dwarfed by grazing to a low sward with very small leaves. The leaves of the type specimen were obviously taken from heavily grazed plants, and were unrepresentative of the species. The principal characteristics of $Y$. microphylla are its hollow rhizomes, the thickened transparent exterior leaf edge, and its smooth culms, with persistent wax below the nodes. The flowers are still not known.

The two Tibetan species were given detailed descriptions although the type specimens are infertile. Y. yadongensis seems very close to $Y$. microphylla, but the description does not mention the hollow rhizomes or thickened leaf margins, which are the principal characteristics of the latter species. It was described from material collected near Yatung in the Chumbi Valley between Sikkim and Bhutan. Y. xizangensis seems from its description to be close to $Y$. maling. It was collected in Tibet to the north of eastern Bhutan and in Arunachal Pradesh, and differs from $Y$. maling in having no leaf sheath auricles or oral setae. The species known from Nepal and Bhutan are keyed out below.

\section{KEY TO YUSHANIA SPECIES IN NEPAL AND BHUTAN}

1a. Rhizome neck hollow Y. microphylla

1b. Rhizome neck solid 2

2a. New culm sheath base glabrous or with small deciduous ring of hairs Y. maling

2b. New culm sheath base with prominent and persistent ring of hairs 3

3a. Leaf sheath auricles large and persistent, oral setae spreading widely Y. hirsuta

3b. Leaf sheath auricles small or absent, oral setae erect Y. pantlingii

\section{ENUMERATION OF SPECIES IN NEPAL AND BHUTAN}

1. Yushania hirsuta (Munro) R.B. Majumdar in Karthikeyan, S. et al., FI. In. Enumerat. Monocot.: 283 (1989).

Type: India, Khasi Hills, Griffith K.D. 6726 (lecto., selected by Chao \& Renvoize 1989, K). Syn.: Arundinaria hirsuta Munro, Trans. Linn. Soc. London 26: 30 (1868); Sinarundinaria hirsuta (Munro) Chao \& Renvoize, Kew Bull. 44(2): 355 (1989).

Representative specimen:

BHUTAN: Thimphu, Yosipang, $27^{\circ} 28^{\prime} \mathrm{N} 89^{\circ} 42^{\prime} \mathrm{E}, 2600 \mathrm{~m}$, Stapleton 858 (THIM). 
2. Yushania maling (Gamble) R.B. Majumdar in Karthikeyan, S. et al., Fl. In. Enumerat. Monocot.: 283 (1989).

Type: India, Darjeeling district, Tonglo, v 1904, Osmaston s.n. (lecto., selected by Chao \& Renvoize 1989, K).

Syn.: Arundinaria maling Gamble, Kew Bull. Misc. Inform.: 139 (1912); Sinarundinaria maling (Gamble) Chao \& Renvoize, Kew Bull. 44(2): 356 (1989).

Representative specimens:

NEPAL: Sankhuwasabha dist., Barun Khola, Emery 20; 21; 102; 146; 147 (BM).

BHUTAN: Chhukha dist., Bunakha, Stapleton 882 (THIM); Chhukha dist., Gedu, $40.5 \mathrm{~km} \mathrm{~N}$. of Phuntsholing, $2100 \mathrm{~m}, 26^{\circ} 55^{\prime} \mathrm{N} 89^{\circ} 32^{\prime} \mathrm{E}, 8$ i 1991, Stapleton 904 (THIM).

Local names: maling, malingo, khosre malingo (Nepali).

3. Yushania microphylla (Munro) R.B. Majumdar in Karthikeyan, S. et al., Fl. In. Enumerat.Monocot.: 283 (1989).

Type: Bhutan, Tashigang district, Sana, Griffith Itin. 623 (holo. K).

Syn.: Bambusa microphylla [Griffith, Journ.: 242 (1847) nom. nud.]; Arundinaria microphylla Munro, Trans. Linn. Soc. London 26: 32 (1868); Sinarundinaria microphylla (Munro) Chao \& Renvoize, Kew Bull. 44(2): 354 (1989).

Representative specimens:

BHUTAN: Paro, Shana, Stapleton 801 (THIM); Thimphu, Changkaphug, Stapleton 821 (THIM); Wangdi, Phubjika, Stapleton 817 (THIM); Tongsa, Pele La, Stapleton 856 (THIM)

NEPAL: Dolakha dist., Mure, Stapleton 457.

4. Yushania pantlingii (Gamble) R.B. Majumdar in Karthikeyan, S. et al., F1. In. Enumerat.Monocot.: 283 (1989).

Type: India [Darjeeling district/Sikkim border], Rechi La, Pantling's collectors s.n. (holo. K).

Syn.: Arundinaria pantlingii Gamble, Ann. Roy. Bot. Gard. (Calcutta) 7: 129

(1896); Semiarundinaria pantlingii (Gamble) Nakai, J. Arnold. Arbor.

6: 151 (1925); Butania pantlingii (Gamble) Keng f., J. Bamboo Res.

1(2): 31 (1982); Sinarundinaria pantlingii (Gamble) Chao \& Renvoize,

Kew Bull. 44(2): 359 (1989).

Representative specimens:

BHUTAN: Tongsa dist., Changkha to Chendebji, 2400m, Wood 6289 (THIM, E); Tashigang,

Stapleton $431 \mathrm{lb}$ (THIM).

Local name: hima (Dzongkha).

Nepal collections cited in Chao \& Renvoize (1989) are not this species, but Borinda emeryi Stapleton.

\section{ACKNOWLEDGEMENTS}

The research for this enumeration was funded by the Overseas Development Administration under Forestry Research Programme grants R4195 and R4849. Final preparation of the CRC 
was supported by the Anglo-Hong Kong Trust. The fieldwork was undertaken while the author was a Research Fellow in the Forestry Department of the University of Aberdeen. Forestry Department and Finance Section staff are thanked for their assistance and support in the administration of the project. Staff in the Forest Department of the Royal Government of Bhutan and in the Forest Research and Information Centre in Kathmandu are thanked for their assistance in the field, along with the staff of many forestry and agricultural projects in Nepal and Bhutan. The Royal Botanic Garden Edinburgh provided office space, technical support, and library facilities during writing up, in return for overhead fees provided by the Forestry Research Programme. The keepers of the herbaria at the Royal Botanic Gardens at Kew and Edinburgh, the Natural History Museum (BM), and the Forest Research Centre, Taba, Thimphu, are thanked for allowing reference to their collections. Dr Robert Mill is thanked for assistance with the Latin diagnoses. David Long and Henry Noltie are thanked for critical reading of the manuscript.

\section{REFERENCES}

BoR, N. L. (1958). Notes on Asiatic grasses: XXX New bamboos. Kew Bull. 12(3): 420.

Burkill, I. H. (1953). Chapters on the history of botany in India I. J. Bombay Nat. Hist. Soc. 51(4): 846-878.

CAMPbell, J. J. N. (1988). Notes on Sino-Himalayan bamboo species. Unpublished manuscript: 1-105. School of Biological Sciences, Lexington, Kentucky.

ChaO, C. S., ChU, C. D. \& HsiunG, W. Y. (1980). A revision of some genera and species of Chinese bamboos. Acta Phytotax. Sin. 18: 20-36.

ChaO, C. S. \& Renvolze, S. A. (1989). A revision of the species described under Arundinaria (Gramineae) in Southeast Asia and Africa. Kew Bull. 44(2): 349-367.

Clayton, W. D. \& Renvoize S. A. (1986). Genera Graminum: Grasses of the World. Royal Botanic Gardens, Kew.

Demoly, J.-P. (1991). Recensement des bambous cultivés en Europe. Bambou - Association Europeene du Bambou - Section France 8: 20-28.

Franchet, M. A. (1893). Fargesia, nouveau genre de Bambuseés de la Chine. Bull. Mens. Soc. Linn. Paris 2: 1067-1069.

Gamble, J. S. (1896). The Bambuseae of British India. Ann. Roy. Bot. Gard. (Calcutta) 7(1): 1-133.

Gamble, J. S. (1912). The Arundinarias of the hills of Sikkim. Kew Bull. Misc. Inform. (1912): $135-140$.

KENG, P. C. (1957). One new genus and 2 new species of Chinese bamboos. Acta Phytotax. Sin. 6: 355-360.

KENG, P. C. (1982a). A revision of genera of bamboos from the world I. J. Bamboo Res. 1(1): 1-19.

KENG, P. C. (1982b). A revision of genera of bamboos from the world II. J. Bamboo Res. 1(2): $31-46$.

KENG, P. C. (1983). A revision of genera of bamboos from the world III. J. Bamboo Res. 2(1): $11-27$. 
KENG, Y. L. \& KenG, P. C. (1959). In: KENG, Y. L. (ed.) Chung-kuo chu yao chih wu tu shuo. Ho pen ko/ho bien. (Flora Illustrata Plantarum Primerum Sinicarum Gramineae). Science Publishing House, Beijing.

MAJUMdar, R. B. (1989). In: KARTHIKEYAN, S. et al., Flora Indicae, Enumeratio Monocotyledonae, pp. 274-283. Botanical Survey of India, Howrah, Calcutta.

MCClure, F. A. (1973). Genera of bamboos native to the new world. Smithsonian Contr. Bot. 9: $1-148$.

MUNRo, W. (1868). A monograph of the Bambusaceae. Trans. Linn. Soc. London 26: 1-157.

NAKAI, T. (1935). Novitates Bambusacearum In Imperio Japonico Recentissime Detectae III. J. Jap. Bot. 11(1): 1-9.

RENVOIZE, S. A. (1993). Sinarundinaria nitida - in flower. Bamboo Soc. (G.B.) Newsletter 17: 24.

SODERSTROM, T. R. (1979a). The bamboozling Thamnocalamus. Garden 3(4): 22-27.

SODERSTROM, T. R. (1979b). Another name for the umbrella bamboo. Brittonia 31(4): 495.

Soderstrom, T. R. \& Ellis, R. P. (1987). The position of bamboo genera and allies in a system of grass classification. In: SODERSTROM, T. R. et al. (eds.) Grass Systematics and Evolution, pp. 225-238. Smithsonian Institution Press.

StAPLETON, C. M. A. (1991). A morphological investigation of some Himalayan bamboos with an enumeration of taxa in Nepal and Bhutan. Unpublished $\mathrm{Ph} \mathrm{D}$ thesis, University of Aberdeen.

StAPleton, C. M. A. (1993). Fargesia macclureana, a Tibetan bamboo in Europe. Bamboo Soc. (G.B.) Newsletter 17: 17.

Stapleton, C. M. A. (1994). The bamboos of Nepal and Bhutan Part I: Bambusa, Dendrocalamus, Melocanna, Cephalostachyum, Teinostachyum, and Pseudostachyum (Gramineae: Poaceae, Bambusoideae). Edinb. J. Bot. 51(1): 1-32.

Stapleton, C. M. A. \& Tamrakar, S. M. (1983). Pipar Bamboos. Appendix in: Picozzi, N. An ecological survey of a proposed reserve for Himalayan pheasants. I.T.E. Project 839 Report, NERC. London.

YI, T. P. (1983). New species of Fargesia and Yushania from Tibet. J. Bamboo Res. 2 (2): 1852 . 